\title{
Pediatric Terrorism Preparedness National Guidelines and Recommendations: Findings of an Evidenced-based Consensus Process
}

\author{
DAVID MARKENSON and IRWIN REDLENER
}

\begin{abstract}
A cadre of experts and stakeholders from government agencies, professional organizations, emergency medicine and response, pediatrics, mental health, and disaster preparedness were gathered to review and summarize the existing data on the needs of children in the planning, preparation, and response to disasters or terrorism. This review was followed by development of evidence-based consensus guidelines and recommendations on the needs of children in disasters, including chemical, biological, and radiological terrorism. An evidence-based consensus process was used in conjunction with a modified Delphi approach for selection of topic areas and discussion points. These recommendations and guidelines represent the first national evidence-based standards for pediatric disaster and terrorism preparedness.
\end{abstract}

$\mathbf{T}$ HE NEEDS OF CHILDREN must be considered during planning and preparation for disasters and terrorist events. There are unique pediatric considerations that need to be addressed during this process:

- The developmental abilities and cognitive levels of children may impede their ability to escape danger.

- Children have unique psychological vulnerabilities, so special management plans are needed in the event of mass casualties and evacuation.

- Emergency medical service (EMS), medical, and hospital staff may not have pediatric training, equipment, or facilities available.

With respect to planning for and responding to terrorism events, children have unique vulnerabilities and require specific equipment and interventions that must be consid- ered. In addition, emergency responders, medical professionals, and health-care institutions require special expertise and training to ensure optimal care of children who are exposed to biological, chemical, or nuclear agents. Examples of the considerations relevant to children include:

- Children cannot be decontaminated in adult decontamination units.

- Children are more vulnerable to chemical agents that are absorbed through the skin or are inhaled.

- Children have special susceptibilities to dehydration and shock from biological agents.

- Children require different dosages or different antibiotics and antidotes to many agents.

- Children are more susceptible to the effects of radiation exposure and require a more vigorous medical response than do adults.

David Markenson, MD, FAAP, EMT-P, is Deputy Director of the National Center for Disaster Preparedness, Director of the Program for Pediatric Preparedness, and Assistant Professor of Population and Family Health at the Columbia University Mailman School of Public Health, and Assistant Professor of Pediatrics at the Columbia University College of Physicians and Surgeons, New York City. Irwin Redlener, MD, FAAP, is Director of the National Center for Disaster Preparedness and Professor of Pediatrics and Public Health at the Columbia University Mailman School of Public Health. 
These unique pediatric needs have rarely been considered in previous planning and preparedness efforts ${ }^{1}$ and may not be sufficiently understood or considered in current disaster planning. This is especially true for the specific challenges associated with recognizing and responding to biological, chemical, or nuclear weapons. Also, far less has been done to create support systems specifically for children compared with such systems for adults. Therefore, the current adult models and guidelines cannot be applied to the care of children. Rather, it is essential to define the needs of children and to develop plans that specifically address their care.

\section{DISASTER PLANNING}

Integrating pediatric needs into federal, state, regional, and local disaster planning is critical. According to unpublished data produced by FEMA in 1997, no state disaster plans included pediatric issues at that time. Disaster planning must consider the needs of children in various settings, including children who are at home, in school or daycare, or in transit, as well as children who for various reasons cannot be reunited with their families. Children with special health-care needs are particularly vulnerable, especially if their survival depends on medications or technologies (e.g., respirators) that may not be readily available during an emergency.

The literature addressing the needs of children in disasters and disaster planning is sparse. The body of literature concerning disaster events, or response and planning for disasters, almost exclusively addresses the needs of adults. Some limited studies of the needs of children in disasters have been done, but few go beyond identifying and treating posttraumatic stress disorder (PTSD). ${ }^{2-9} \mathrm{~A}$ MEDLINE search of articles published during the past 20 years, using the keyword "disaster," found more than 4,000 entries. However, only 350 of these entries concerned children, and close to $95 \%$ of those reported primarily on PTSD. Thus, while it is clear that there is a basic body of literature on PTSD in children, there are only a few articles on other aspects related to children and disasters.

A review article for Critical Care Clinics in 1991 by Holbrook et al. ${ }^{10}$ was one of the first that attempted to define some of the unique aspects of the response to the needs of children in disasters. While based on only limited evidence, this article provided some basic information that can guide future study. An article from England by Carley reported the results of a Delphi study used to identify and improve areas of concern in medical care for children during the planning, response, and recovery phases of major incidents. " This was not data-based but represents the well-formulated recommendations from a consensus of experts. The authors concluded that "the common theme is not that planning for children failed but rather that planning for children did not exist." Mackway-Jones then published a paper describing how the Delphi study and consensus recommendations could be implemented to improve care for children. ${ }^{12}$ The benefit of this article is that it "presented a logical approach on how to incorporate these recommendations to allow for planning of the rare but potentially devastating effects of a major incident involving children."

\section{Evidence-based studies}

There also have been a limited number of studies based on evidence obtained from actual disasters (described below). While not global in scope, these articles highlight the needs of children and provide concepts for studying whether these needs are met in specific disaster incidents. In 1993, van Amerongen et al. ${ }^{13}$ studied the EMS response to a plane crash that had 135 survivors, 22 of whom were children. These authors found that children were not adequately triaged or transported to appropriate facilities that had been designated for children before the event. The authors called for higher levels of pediatric planning within the existing disaster plan. In 1994, Quinn et al. ${ }^{14}$ reported that Hurricane Andrew was associated with an increase in admissions to a pediatric emergency. department for open wounds, kerosene ingestions, and gastrointestinal illness. The authors recommended patient education to lower risk after similar devastating or disruptive events.

Takeda et al. ${ }^{15}$ retrospectively reviewed the impact of a major earthquake in Japan on the condition of 678 families of children with special health-care needs. These authors identified unmet needs and problems for the families. Shimada and Funato studied 28 children on mechanical ventilation who lived through the same major Japanese earthquake. ${ }^{16}$ Although none of the children died, 19 had major medical problems during and after the earthquake, and the need for better planning and preparation was recognized. Lamburg ${ }^{17}$ examined the intensive, prolonged, and complicated psychological needs experienced by children after the violence associated with the Waco and Dunblane events. The conclusion was that there was no easy solution to this problem and that significant resources would be required to provide real support in this and similar settings.

Damien et al. ${ }^{18}$ gave a firsthand account of a pediatric relief team that traveled to St. Thomas immediately after a major hurricane. The team took care of 100 patients daily, ranging from critically ill children to those with open wounds or routine problems. These authors demonstrated the value of Disaster Medical Assistance Teams (DMATs) focused on the needs of children, and they 
called for significant training of such teams to function in austere environments.

\section{Policy guidelines from professional societies}

Only recently have professional organizations begun to develop policy guidelines considering the needs of children during and after disasters. Such policies tend to focus on the roles of specific providers in disaster planning, preparation, and response. Examples would be statements from the American Academy of Pediatrics such as The Pediatrician's Role in Disaster Preparedness and How Pediatricians Can Respond to the Psychosocial Implications of Disasters. ${ }^{19,20}$

Policy statements by national professional organizations are not comprehensive in scope and are often based on little actual evidence. As such, they represent only a "best advice" approach. Furthermore, such policies do little to ensure an organized response to pediatric disasters, unless they are both explicitly endorsed by local public health and safety authorities and fully integrated into local disaster preparedness initiatives.

\section{Need for a consistent approach}

Without a consistent approach from state to state, it will be difficult, if not impossible, for national pediatric professional organizations to educate their members about their roles and responsibilities during disasters affecting children. Furthermore, a consistent national approach is needed to empower state offices of emergency management, local public health and safety authorities, local chapters of national pediatric professional organizations, and members of such organizations to accomplish a number of tasks, including:

- conceptualizing and integrating the roles and responsibilities of pediatric health professionals during natural or technological disasters;

- building partnerships that will allow a rapid and integrated response to a disaster;

- conducting the advance planning that is necessary to ensure a timely and appropriate response by the involved parties; and

- collaborating effectively in time of need.

\section{TERRORISM PLANNING}

It is even more important to consider children in terrorism planning and preparedness than in traditional disaster planning. Thinking formerly was focused on military personnel as the potential victims of biological, chemical, or radiological attacks. Thus, the treatments, antidotes, and research needed to help such victims were based on the needs of adults. Unfortunately, today the entire population, including communities, families, and children, are at risk of experiencing a terrorist event that involves biological, chemical, or radiological weapons. As a result, current efforts must include research, planning, and preparation for pediatric victims of terrorist events.

Emergency planners and emergency responders must shift their thinking to include the care of all victims in times of terrorist events. This includes considering children as possible victims and planning for their needs during training and equipment allocation. Most important, emergency planners and responders cannot approach the care of children by simply modifying current practices. The unique anatomy and physiology of children necessitates a unique approach to assessment and treatment, including the use of pediatric-specific equipment and medications, which must be dosed appropriately according to age and weight.

As with general planning for disasters, a consistent approach among states is needed to address the needs of children during terrorist events. Otherwise, it will be difficult, if not impossible, for providers to learn about their specific roles and responsibilities during disasters affecting children. In addition, plans and stockpiles need to adequately address the needs of children. And consistency is needed in evaluation models and exercises and drills to test disaster and terrorism preparedness for children.

Evaluating the existing data on the needs of children in disasters and formulating appropriate guidelines and recommendations are necessary to correct deficiencies in national planning for the impact of terrorism on children. Unfortunately, as with disaster planning, there is a sparse literature addressing terrorism preparedness and the needs of children. This topic was covered somewhat in a review on chemical-biological terrorism and children. ${ }^{21}$ However, an article describing medical preparedness for terrorist incidents at the Atlanta Olympics, along with recommendations for such events, did not address children and their special needs, nor did it reference other resources that did.22 A series of important policy and review papers on biological and chemical warfare also failed to address pediatric issues. ${ }^{23-25}$ Consensus must be established in those areas for which data do not exist, and a research agenda to fill the identified voids must be developed and implemented.

\section{The Public Health Security and Bioterrorism Preparedness and Response Act}

In 2002, the President signed the Public Health Security and Bioterrorism Preparedness and Response Act. This Act started the process of improving our bioterrorism preparedness, but the attention to pediatrics was lim- 
ited. The only specific consideration of children was in the creation of a National Advisory Committee on Children and Terrorism (NACCT) (for which the authors serve as consultants). The objective of the NACCT, as specified in the legislation, is to assess and provide recommendations to the Secretary of the Department of Health and Human Services in a number of areas:

- The preparedness of the health-care system to respond to bioterrorism as it relates to children;

- Needed changes to the health-care and emergency medical service systems, including protocols to meet the special needs of children; and

- Changes, if necessary, to the National Strategic Stockpile (under section 121 of the Act) to meet the emergency health needs of children.

While this provision was helpful in providing recommendations to the Secretary, it neither required that such recommendations be enacted nor provided funding for them.

All other sections of the Act were implemented almost immediately, but the advisory committee on children and terrorism was not appointed until March 2003, and this committee had only until June 2003 to issue a final report. Therefore, the committee based their focus areas, recommendations, and guidelines on those developed at the consensus conference and presented in this article. This decision was made in an effort to achieve maximal efficiency using the most current national information available.

\section{METHODOLOGY}

The methodology used to develop the guidelines and recommendations in the current report was one of a previously validated evidence-based consensus process ${ }^{26}$ that has been used in prior studies, supplemented by a modified Delphi ${ }^{27-30}$ approach for topic selection. We convened experts from multiple disciplines and areas of expertise involved in the planning for and care of children during times of disaster and terrorist events. This process had several goals:

- Build collaboration among individuals with expertise in pediatrics, pediatric emergency medicine, pediatric critical care, pediatric surgery, and emergency management (including disaster planning, management, and response).

- Review and summarize the existing data on the needs of children in disaster planning, preparation, and response.

- Develop evidence-based guidelines and recommendations on the needs of children in disasters, and develop evidence-based consensus guidelines for dealing with gaps in the evidence.

- Create a research agenda to address knowledge gaps based on the limited data that exist on the needs of children in disasters.

\section{Panel selection}

An initial planning meeting was held in the winter of 2002. The overall aim was to identify a multidisciplinary group of experts in the field of pediatric emergency preparedness and to develop a conference format and agenda. At this meeting, panel co-chairs were selected, and the format and composition of the consensus panel were established.

All panelists were selected on the basis of research or clinical expertise in pediatrics and emergency preparedness, as well as their position as "thought leaders" in this emerging field. The participants in this process were selected before the topics were selected, and participants represented a cross-section of those with expertise, responsibility, and authority to make decisions that would affect pediatric preparedness for disaster and terrorist events. Participants also had expertise regarding the effects of biological, chemical, and radiological terrorism on children. Many also had knowledge and expertise regarding the psychological stress faced by children and families since September 11. Participants included representatives from various pediatric health organizations, including:

- Representatives from relevant professional organizations;

- Representatives of multiple federal, state, and local government agencies involved with disaster and terrorism preparedness; and

- Experts in the fields of emergency medicine, pediatrics and its subspecialties, pediatric disaster medicine, nursing, social work, mental health, and emergency management. These included recognized national experts in relevant subject areas.

Staff members from the Children's Health Fund and the Program for Pediatric Preparedness provided support for both the process and the face-to-face meeting. The names of potential experts were provided by specialty societies. Authorship on key publications was considered during the selection process. The final consensus panel comprised 72 experts from a wide range of disciplinary backgrounds. Each panelist fulfilled the aforementioned criteria and is currently involved in research on or practice of emergency preparedness. Attendance for the entire time of the consensus conference meeting was required. The names of the organizations, agencies, and representatives can be found in Appendix A. 


\section{Topic selection}

The topics to be covered by the consensus process and for which recommendations and guidelines were to be developed were selected using a modified Delphi approach. The modified Delphi process included submission of topics, followed by three rounds of voting by the planning committee to determine the top eight areas for discussion and the subtopics for each.

\section{Literature review}

Six months before the consensus meeting, group leaders were selected to review and grade the literature (with the assistance of grant staff) and to develop a rating system for recommendations. Grading and rating used the evidence-based scoring system published by the American College of Critical Care Medicine (Figure 1). ${ }^{31}$ The literature was generated by a MEDLINE search using the following age-limited keywords/phrases: disaster, terrorism, preparedness, bioterrorism, chemical terrorism, radiological terrorism, and disaster mental health. Because the available pediatric data were scarce, the search was then expanded by removing the age limitation.

\section{The consensus meeting}

The consensus panel meeting in Washington, DC, consisted of closed-session deliberations that involved several key decision-making components. Before the confer-

Figure 1. american College of Critical Care MEDiCiNE Guidelines For RATING LiteratuRE AND RECOMMENDATIONS BASED ON QUALITY AND STRENGTH OF EVIDENCE

\section{Rating system for references}

A. Randomized, prospective controlled trials

B. Nonrandomized, concurrent, or historical cohort investigations

C. Peer-reviewed, state-of-the-art articles, review articles, editorials, or substantial case series

D. Non-peer-reviewed published opinions, such as textbook statements or official organizational publications

\section{Rating system for recommendations}

Level I: Convincingly justifiable on scientific evidence alone

Level II: Reasonably justifiable by scientific evidence and strongly supported by expert critical care opinion

Level III: Adequate scientific evidence is lacking but widely supported by available data ence, all panelists were provided with a complete bibliography, as well as summaries of the available evidence within their topic areas. A meeting agenda and list of objectives also were provided in advance. At the conference, panelists were provided with the evidence-based summaries of all topics, as well as the primary literature sources.

The meeting, which lasted more than 40 hours, was conducted using a previously validated evidence-based approach, according to the following format:

- Experts in the subject area to be addressed presented baseline evidence (including evidence review and grading);

- Breakout groups were formed for focused discussion on topics within each subject area; and

- The entire group reconvened to review conclusions reached by each breakout group and to develop formal recommendations and guidelines.

The consensus development method employed at this meeting involves intensive review of specific topic areas by expert panels, structured group discussions, and consensus voting according to a strict mathematical formula. The approach is widely referred to as the Rand method for medical decision-making and technology assessment. Fundamental elements include panel selection, development of appropriateness scales and panel preparation, and the modified Delphi technique for topic selection coupled with group decision-making and consensus development. This approach synthesizes the opinions of clinicians and research experts and is designed to develop consensus guidelines for a broad range of clinical situations. The advantages are cost-effectiveness and timeliness, as the method draws on a broad base of clinical and research data. The principal disadvantages are the limitations of currently available data and the subjective nature of the group decision-making process.

\section{The recommendations and guidelines}

The recommendations and guidelines were drafted using the approach already discussed. This process began with a review of current epidemiological data on pediatric preparedness. Subsequently, the panel began consensus deliberations, using the Rand methodology, for development of the treatment recommendations and guidelines. Panelists were invited to base judgments on personal opinions about the evidence, not on the position of the society that may have nominated them.

A staged approach was used to achieve this consensus. In the first stage, panelists voted on whether a particular guideline or recommendation was appropriate. If no 
agreement was reached, further discussion occurred and the vote was retaken. A maximum of two votes was permitted on any specific issue. Conference attendees then commented on the draft recommendations and guidelines, which were modified accordingly. This process was continued until consensus was reached.

During the meeting, "consensus" for any specific or general recommendation or guideline was defined as disagreement by only $10 \%$ or less of attendees. In actuality, agreement was unanimous on all recommendations and guidelines.

It is important to remember that the group leaders identified almost no randomized controlled trials in children relating to disaster and terrorism preparedness, except for those addressing mental health considerations (as noted above). Because of this lack of data from randomized trials in children, many of the recommendations in this document represent either extrapolations from adult data, an application of nonpreparedness research to preparedness guidelines, or expert opinion rather than irrefutable evidence.

Following the meeting, the final report from each subcommittee was compiled into a comprehensive document by the group leader, a process that took 6 months. Final copyediting and review were performed by the authors.

\section{RESULTS}

The final recommendations of the conference focused on eight major areas:

1. Emergency and prehospital care

2. Hospital care

3. Terrorism preparedness and response

3.1. Biological terrorism

3.2. Chemical terrorism

3.3. Radiological terrorism

3.4. Physical protection

3.5. Decontamination

3.6. Strategic National Stockpile (SNS)

The specific recommendations can be found below.

\section{Emergency and prehospital care}

The cornerstone of emergency preparedness and terrorism response rests with the first responders. They provide not only the initial care but also the initial assessment. This is critical to ensure that all patients receive the care they need, while appropriately allocating scarce resources during disaster and terrorist events. Therefore, any emergency response planning must begin with well- trained and well-equipped first responders who are prepared to perform triage and to provide the needed care. Figure 2 presents recommendations that address the minimal elements for proper triage and prehospital care of children by first responders.

\section{Hospital care}

Medical preparedness depends on a combination of public health direction and general hospital preparedness. Hospital preparedness encompasses a wide range of issues, including preparedness of both the physical facility and the staff. The hospital also serves as a regional resource to other health-care facilities, as well as the medical oversight and training resource for first responders. In addition, hospitals are a key resource of trained staff who may be needed in times of emergency, or by other facilities, or both.

Specialty resource centers also play an important role in emergency preparedness. Specialty resource centers are defined as facilities with unique capabilities beyond those expected of any general hospital and that have received designation in a specific area of expertise from an appropriate accrediting organization. Examples include trauma centers, burn centers, hyperbaric centers, and pediatric critical care centers.

All of the above elements are important considerations with regard to the needs of children. During a disaster or terrorist event, children will undoubtedly arrive at general hospitals, so all hospitals must be prepared for a greater number of pediatric victims than usual. Specialty centers must also be prepared for increased pediatric needs. Staff and physician volunteer programs that are key to ensuring adequate numbers of providers must also recognize the need for more pediatric-trained providers. Currently, the availability of providers who have pediatric training is limited. The recommendations found in Figures 3 and 4 address hospital preparedness, specialty centers, physician volunteers, and the role of the children's hospital.

\section{Biological, chemical, and radiological terrorism preparedness}

Once the general needs of children have been addressed, preparedness specifically for a terrorist event must be considered. The unique physiology and anatomy of children make them more susceptible to terrorist agents, and unique therapies may be required.

Biological terrorism. The consensus panel agreed that all plans for providing bioterrorism medication must include all medications listed in Tables 1 and 2, including appropriate pediatric forms and dosages. This would include stocking and deployment of these agents (push packs, vendor-managed inventory, etc.) through the SNS and state and local health departments. The panel also 
Figure 2. Recommendations for Triage and Prehospital Care

\section{Triage}

- Incorporate use of a pediatric-specific triage system by all first responders and hospital personnel. At this time, JumpSTART Pediatric Multiple Casualty Incident Triage is the only objective triage system that addresses the needs of children. It provides guidance for triage personnel making potential life-and-death decisions that otherwise may be influenced by emotional issues when triaging children.

- Designate a pediatric-specific triage process (currently, JumpSTART, as described above) for use in training by first responders and emergency personnel.

- Continue to develop, improve, and implement triage systems that are objective and child-specific to advance the efficiency and accuracy of triage.

- Ensure integration and consistency of use of pediatric triage processes among local, state, and federal responders, including Disaster Medical Assistance Teams (DMATs).

- Develop and use pediatric-specific triage systems that address primary, secondary, and tertiary triage.
These should address all aspects of disaster triage, including psychological triage, triage for weapons of mass destruction (WMD), and triage for children with special health-care needs.

- Include evaluation of triage processes and performance in quality assessment procedures (performed after the event) at local and state levels, as well as in future research initiatives.

\section{Prehospital Care}

- Equip EMS personnel and response vehicles with pediatric-specific equipment and medications. This includes supplies for decontamination and assessment/treatment for biological, chemical, and radiological terrorism.

- Establish model guidelines and best practices for communication, documentation, community involvement, equipment, medical oversight, and strong Incident Command Systems, protocols for basic life support and advanced life support, children with special health-care needs, and schools (both public and private). agreed that there should be treatment provisions for local responders. The consensus process further defined the chemotherapy and chemoprophylaxis protocols listed in Tables 1 and 2.

The issues of immunotherapy and immunoprophylaxis also were reviewed. The committee concluded that provision must be made for the study and use of investigational vaccines in children. The currently licensed anthrax vaccine (Anthrax Vaccine Adsorbed, AVA, Bioport, Lansing, Mich.) is approved only for people 18-65 years old. This vaccine may have a limited role as an adjunct to postexposure chemoprophylaxis, although data are limited. There is only limited potential for use of this vaccine in a civilian pre-exposure setting, but the participants felt that future studies of new-generation anthrax vaccines should include children.

\section{Figure 3. ReCOMmENDATIONS For Hospital PREPAREDNESS}

- Ensure preparedness in all hospitals, with children's hospitals playing a crucial role in educating the community, training health-care providers, and directing the care of children in general hospitals when the numbers of children or logistics prevent transport to a children's hospital.

- Keep a 48-hour supply of pediatric equipment and pharmaceuticals on hand for the average daily number of patients plus an additional 100 patients.

- Include a detailed pediatric component in Web-based hospital resource availability networks.

- Engage in a pediatric-specific disaster risk assessment with the community, including school districts, the office of emergency services, EMS, the police depart- ment, the fire department, private practitioners, child welfare organizations, childcare establishments, public health organizations, and mental health facilities.

- Develop informational resources and training for pediatric-specific responses to biological, chemical, and radiological terrorism.

- Ensure that all hospital emergency operations and preparedness policies include pediatric care and treatment guidelines and account for the unique aspects and needs of children.

- Ensure that all agents and equipment that are stocked for disaster and terrorism preparedness are either specifically for pediatric use or can be appropriately substituted for pediatric use. 
Figure 4. Recommendations for Specialty Resource Centers, Metropolitan Medical Response Systems, COMMUNITY RESPONSE TEAMS, AND PHySician VOLUNTEERS

- Designate a pediatric specialty resource center and system in every regional and state disaster plan to include—at a minimum-pediatric critical care, pediatric trauma, and pediatric burn capabilities.

- Form disaster medical and psychological incident response teams capable of managing pediatric patients in every region. The Metropolitan Medical Response System (MMRS) and Community Response Teams must plan for and receive training in the care of pediatric patients. The MMRS must include appropriately trained providers and provision for pediatric equipment.
- Promote communication and consultation between facilities by availability of multiple horizontal communication systems that include patient records and medical information.

- Involve pediatric-trained providers in physician volunteer programs. Such programs must have plans to provide pediatric-trained providers to facilities that need additional support in disaster events.

- Fund regional planning efforts.

- Develop multiple systems capable of transporting pediatric patients to link patient care resources.

Table 1. Recommended Therapy and Prophylaxis of Anthrax in Children

\begin{tabular}{|c|c|c|}
\hline Form of anthrax & $\begin{array}{l}\text { Category of treatment } \\
\text { (therapy or prophylaxis) }\end{array}$ & Agent and dosage \\
\hline Inhalational & $\begin{array}{l}\text { Therapy } \\
\text { Patients who are clinically } \\
\text { stable after } 14 \text { days can be } \\
\text { switched to a single oral } \\
\text { agent (ciprofloxacin or } \\
\text { doxycycline) to complete a } \\
\text { 60-day course }{ }^{\mathrm{b}} \text { of therapy. }\end{array}$ & 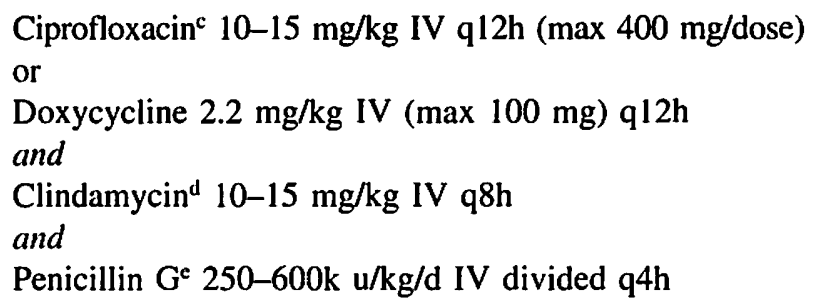 \\
\hline Inhalational & $\begin{array}{l}\text { Post-exposure prophylaxis } \\
\quad\left(60 \text {-day course }{ }^{\mathrm{b}}\right)\end{array}$ & $\begin{array}{l}\text { Ciprofloxacin } 10-15 \mathrm{mg} / \mathrm{kg} \text { PO } \\
(\max 500 \mathrm{mg} / \mathrm{dose}) \mathrm{q} 12 \mathrm{~h} \\
\text { or } \\
\text { Doxycycline } 2.2 \mathrm{mg} / \mathrm{kg}(\max 100 \mathrm{mg}) \text { PO } \mathrm{q} 12 \mathrm{~h}\end{array}$ \\
\hline Cutaneous, endemic & Therapyg & $\begin{array}{l}\text { Penicillin V 25-50 mg/kg/d PO divided q6h or } \\
\text { Amoxicillin } 40-80 \mathrm{mg} / \mathrm{kg} / \mathrm{d} \text { PO divided q8h or } \\
\text { Ciprofloxacin } 10-15 \mathrm{mg} / \mathrm{kg} \text { PO (max } 1 \mathrm{gm} / \mathrm{day}) \mathrm{q} 12 \mathrm{~h} \text { or } \\
\text { Doxycycline } 2.2 \mathrm{mg} / \mathrm{kg} \text { PO (max } 100 \mathrm{mg}) \mathrm{q} 12 \mathrm{~h}\end{array}$ \\
\hline $\begin{array}{l}\text { Cutaneous (in setting } \\
\text { of terrorism) }\end{array}$ & Therapyg & $\begin{array}{l}\text { Ciprofloxacin } 10-15 \mathrm{mg} / \mathrm{kg} \text { PO }(\max 1 \mathrm{gm} / \text { day) } \mathrm{q} 12 \mathrm{~h} \text { or } \\
\text { Doxycycline } 2.2 \mathrm{mg} / \mathrm{kg} \text { PO }(\max 100 \mathrm{mg}) \mathrm{q} 12 \mathrm{~h}\end{array}$ \\
\hline Gastrointestinal & Therapy ${ }^{\mathrm{a}}$ & Same as for inhalational \\
\hline
\end{tabular}

This table was created from recommendations developed at the consensus conference and is based in part on reviewed reference materials from AAP, CDC, FDA, and IDSA.

'In a mass casualty setting, in which resources are severely limited, oral therapy may need to be substituted for the preferred parenteral option. This may be most acceptable for ciprofloxacin, because it is rapidly and well absorbed from the gastrointestinal tract with no substantial loss from first-pass effect.

${ }^{b}$ Children may be switched to oral amoxicillin ( $40-80 \mathrm{mg} / \mathrm{kg} / \mathrm{d}$ divided q $8 \mathrm{~h}$ ) to complete a 60 -day course (assuming the organism is sensitive). We recommend that the first 14 days of therapy or postexposure prophylaxis, however, include ciprofloxacin and/or doxycycline regardless of age. A three-dose series of vaccine may permit shortening of the antibiotic course to 30 days.

'Levofloxacin or ofloxacin may be acceptable alternatives to ciprofloxacin.

'Rifampin or clarithromycin may be acceptable alternatives to clindamycin as drugs that target bacterial protein synthesis. If ciprofloxacin or another quinolone is used, doxycycline may be used as a second agent because it also targets protein synthesis.

'Ampicillin, imipenem, meropenem, or chloramphenicol may be acceptable alternatives to penicillin as drugs with good CNS penetration.

'According to most experts, ciprofloxacin is the preferred agent for oral prophylaxis.

8Ten days of therapy may be adequate for endemic cutaneous disease. However, a full 60-day course is recommended in the setting of terrorism because of the possibility of concomitant inhalational exposure. 
Table 2. Recommended Therapy and Prophylaxis in Children for Additional Select DISEASES ASSOCIATED WITH BIOTERRORISM

\begin{tabular}{|c|c|c|}
\hline Disease & $\begin{array}{l}\text { Therapy or } \\
\text { prophylaxis }\end{array}$ & Treatment, agent, and dosage $\mathrm{e}^{\mathrm{a}}$ \\
\hline Smallpox & $\begin{array}{l}\text { Therapy } \\
\text { Prophylaxis }\end{array}$ & $\begin{array}{l}\text { Supportive care } \\
\text { Vaccination may be effective if given within the first several } \\
\text { days after exposure. }\end{array}$ \\
\hline Plague & Prophylaxis & 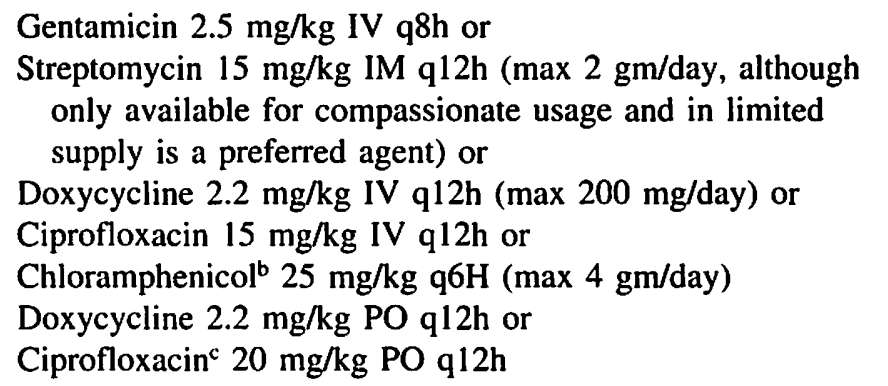 \\
\hline Tularemia & Therapy & Same as for plague \\
\hline Botulism & Therapy & $\begin{array}{l}\text { Supportive care, antitoxin may halt progression of symptoms } \\
\text { but is unlikely to reverse them }\end{array}$ \\
\hline Viral Hemorrhagic Fevers & Therapy & Supportive care, ribavirin may be beneficial in select cases ${ }^{d}$ \\
\hline Brucellosis & Therapy $^{\mathbf{e}}$ & 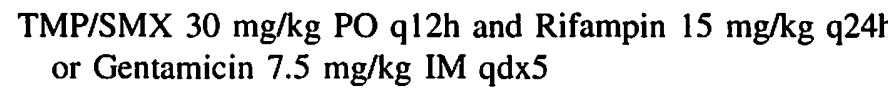 \\
\hline
\end{tabular}

This table was created from recommendations developed at the consensus conference and is based in part on reviewed reference materials from AAP, CDC, and IDSA.

'In a mass casualty setting, parenteral therapy might not be possible. In such cases, oral therapy (with analogous agents) may need to be used.

bConcentration should be maintained between 5 and $20 \mathrm{mcg} / \mathrm{mL}$. Some experts have recommended that chloramphenicol be used to treat patients with plague meningitis, because chloramphenicol penetrates the blood-brain barrier. Use in children younger than 2 years old may be associated with adverse reactions but might be warranted for serious infections.

'Other fluoroquinolones (levofloxacin, ofloxacin) may be acceptable substitutes for ciprofloxacin; however, they are not approved for use in children.

'Ribavirin is recommended for arenavirus and bunyavirus and may be indicated for a viral hemorrhagic fever of an unknown etiology, although it is not FDA approved for these indications. For intravenous therapy use a loading dose: $30 \mathrm{~kg}$ IV once (maximum dose, $2 \mathrm{gm}$ ), then $16 \mathrm{mg} / \mathrm{kg}$ IV every $6 \mathrm{hr}$ for 4 days (maximum dose, $1 \mathrm{gm}$ ) and then $8 \mathrm{mg} / \mathrm{kg} \mathrm{IV}$ every $8 \mathrm{hr}$ for 6 days (maximum dose, $500 \mathrm{mg}$ ). In a mass casualty setting, it may be necessary to use oral therapy. For oral therapy, use a loading dose of $30 \mathrm{mg} / \mathrm{kg}$ $\mathrm{PO}$ once, then $15 \mathrm{mg} / \mathrm{kg} /$ day $\mathrm{PO}$ in 2 divided doses for 10 days.

'For children younger than 8 years. For children older than 8 years, adult regimens are recommended. Oral drugs should be given for 6 weeks. Gentamicin, if used, should be given for the first 5 days of a 6-week course of TMP/SMX (trimethoprim/sulfamethoxazole).

The currently licensed smallpox vaccine (Dryvax, Wyeth, Philadelphia, Penn.) makes no mention in its package insert of an approved age range. This vaccine was routinely administered to 1-year-olds before the early 1970s. The Centers for Disease Control and Prevention (CDC) currently recommends against vaccination of children younger than 1 year. However, all contraindications to smallpox vaccination are relative. After bona fide exposure or known usage of weaponized smallpox, even the youngest exposed or atrisk infants should be vaccinated. Moreover, future studies of new-generation vaccines must include children.

A licensed trivalent (types A, B, E) botulism antitoxin is available through the CDC. This antitoxin is to be used in children of any age known to have been exposed to botulinum toxin of the appropriate serotypes. An IND pentavalent (types A-E) Botulinum Immune Globulin (human) is available through the California Department of Health and is specifically for the treatment of infantile botulism. The panel concluded that study of this product should be continued and licensure pursued. No licensed plague vaccine is currently in production. A previously licensed vaccine was approved only for people 18-61 years old. However, there is little, if any, role for this vaccine or similar vaccines in the context of a bioterrorist attack.

Chemical terrorism. Figures 3 and 4 summarize the comprehensive Panel recommendations for chemical 
Table 3. Recommended Treatment and Management of Chemical Agents

\begin{tabular}{|c|c|c|c|c|c|}
\hline Agent & Toxicity & Clinical findings & Onset & Decontamination $^{\mathrm{a}}$ & Management \\
\hline \multicolumn{6}{|c|}{ NERVE AGENTS } \\
\hline \multirow[t]{3}{*}{$\begin{array}{l}\text { Tabun, sarin, } \\
\text { soman, VX }\end{array}$} & $\begin{array}{l}\text { Anticholinesterase: } \\
\text { muscarinic, } \\
\text { nicotinic, and } \\
\text { CNS effects }\end{array}$ & $\begin{array}{l}\text { Vapor: miosis, } \\
\text { rhinorrhea, } \\
\text { dyspnea }\end{array}$ & Vapor: seconds & $\begin{array}{l}\text { Vapor: fresh air, remove } \\
\text { clothes, wash hair }\end{array}$ & $\begin{array}{l}\text { Airway, breathing, circulatory support } \\
\text { Atropine } 0.05-0.1 \mathrm{mg} / \mathrm{kg} \mathrm{IV}^{\mathrm{b}}, \mathrm{IM}^{\mathrm{c}} \text { (min } \\
0.1 \mathrm{mg}, \max 5 \mathrm{mg} \text { ) repeat } \mathrm{q} 2-5 \mathrm{~min} \text { prn } \\
\text { for marked secretions, bronchospasm, } \\
\text { hypoxia, respiratory compromise, apnea, } \\
\text { cardiopulmonary arrest }\end{array}$ \\
\hline & & $\begin{array}{l}\text { Liquid: Diaphoresis, } \\
\text { vomiting } \\
\text { Both: coma, paralysis, } \\
\text { seizures, apnea }\end{array}$ & $\begin{array}{l}\text { Liquid: minutes } \\
\text { to hours }\end{array}$ & $\begin{array}{l}\text { Liquid: remove clothes, } \\
\text { copious washing of skin } \\
\text { and hair with soap and } \\
\text { water, ocular irrigation }\end{array}$ & $\begin{array}{l}\text { Pralidoxime } 25-50 \mathrm{mg} / \mathrm{kg} \mathrm{IV,IM}{ }^{\mathrm{d}} \\
\text { (max } 1 \mathrm{~g} \mathrm{IV} ; 2 \mathrm{~g} \mathrm{IM} \text { ), may repeat within } \\
30-60 \mathrm{~min} \text { prn, then again qlh for } 1 \text { or } 2 \\
\text { doses prn for persistent weakness, high } \\
\text { atropine requirement }\end{array}$ \\
\hline & & & & & $\begin{array}{l}\text { Diazepam } 0.05-0.3 \mathrm{mg} / \mathrm{kg} \text { (max } 10 \mathrm{mg} \text { ) } \\
\text { IV, lorazepam } 0.1 \mathrm{mg} / \mathrm{kg} \text { IV or IM } \\
\text { (max } 4 \mathrm{mg} \text { ), midazolam } 0.1-0.2 \mathrm{mg} / \mathrm{kg} \\
\text { (max } 10 \mathrm{mg} \text { ) IM prn for seizures or } \\
\text { severe exposure }\end{array}$ \\
\hline \multicolumn{6}{|l|}{ VESICANTS } \\
\hline Mustard & Alkylation & $\begin{array}{l}\text { Skin: erythema, } \\
\text { vesicles }\end{array}$ & Hours & $\begin{array}{l}\text { Skin: soap and water } \\
\text { Eyes: irrigation (water) }\end{array}$ & Symptomatic care \\
\hline Lewisite & Arsenical & $\begin{array}{l}\text { Eye: inflammation } \\
\text { Respiratory tract: } \\
\text { inflammation, } \\
\text { respiratory distress, } \\
\text { acute respiratory } \\
\text { distress syndrome }\end{array}$ & Immediate pain & $\begin{array}{l}\text { Both: major impact } \\
\text { only if done within } \\
\text { minutes of exposure }\end{array}$ & $\begin{array}{l}\text { Possibly British anti-lewisite (BAL) } 3 \mathrm{mg} / \mathrm{kg} \\
\mathrm{IM} \text { q4-6 h for systemic effects of } \\
\text { lewisite in severe cases }\end{array}$ \\
\hline
\end{tabular}




\section{PULMONARY AGENTS}

\begin{tabular}{|c|c|c|c|c|c|}
\hline \multirow[t]{2}{*}{$\begin{array}{l}\text { Chlorine, } \\
\text { phosgene }\end{array}$} & \multirow[t]{2}{*}{$\begin{array}{l}\text { Liberate } \mathrm{HCl} \text {, } \\
\text { alkylation }\end{array}$} & $\begin{array}{l}\text { Eyes, nose, throat } \\
\text { irritation } \\
\text { (especially } \\
\text { chlorine) }\end{array}$ & Minutes & $\begin{array}{l}\text { Fresh air } \\
\text { Skin: water }\end{array}$ & \multirow[t]{2}{*}{ Symptomatic care } \\
\hline & & $\begin{array}{l}\text { Bronchospasm, } \\
\text { pulmonary edema } \\
\text { (especially } \\
\text { phosgene) }\end{array}$ & $\begin{array}{l}\text { Bronchospasm: } \\
\text { minutes } \\
\text { Pulmonary } \\
\text { edema: hours }\end{array}$ & & \\
\hline \multirow[t]{2}{*}{ Cyanide } & \multirow[t]{2}{*}{$\begin{array}{l}\text { Cytochrome } \\
\text { oxidase inhibition: } \\
\text { cellular anoxia, } \\
\text { lactic acidosis }\end{array}$} & \multirow[t]{2}{*}{$\begin{array}{l}\text { Tachypnea, coma, } \\
\text { seizures, apnea }\end{array}$} & \multirow[t]{2}{*}{ Seconds } & \multirow[t]{2}{*}{$\begin{array}{l}\text { Fresh air } \\
\text { Skin: soap and water }\end{array}$} & $\begin{array}{l}\text { Airway, breathing, circulatory support; } \\
100 \% \text { oxygen } \\
\text { Sodium bicarbonate prn for metabolic } \\
\text { acidosis } \\
\text { Sodium nitrate }(3 \%) \text { : }\end{array}$ \\
\hline & & & & & $\begin{array}{cc}\text { Dosage }(\mathrm{ml} / \mathrm{kg}) & \begin{array}{c}\text { Estimated } \mathrm{Hgb}(\mathrm{g} / \mathrm{dl}) \\
\text { for average child }\end{array} \\
0.27 & 10 \\
0.33 & 12 \\
0.39 & 14 \\
\text { Maximum } 10 \mathrm{ml} & \\
\text { Sodium thiosulfate }(25 \%) & 1.65 \mathrm{ml} / \mathrm{kg} \\
\text { (maximum } 50 \mathrm{ml} \text { ) } & \end{array}$ \\
\hline \multicolumn{6}{|c|}{ PULMONARY AGENTS } \\
\hline $\begin{array}{l}\left.\text { CS, CN (Mace }{ }^{\circledR}\right) \\
\text { capsaicin } \\
\text { (pepper spray) }\end{array}$ & $\begin{array}{l}\text { Neuropeptide } \\
\text { substance } P \\
\text { release, } \\
\text { alkylation }\end{array}$ & $\begin{array}{l}\text { Eye: tearing, pain, } \\
\text { blepharospasm } \\
\text { Nose and throat } \\
\text { irritation } \\
\text { Pulmonary failure } \\
\text { (rare) }\end{array}$ & Seconds & $\begin{array}{l}\text { Fresh air } \\
\text { Eye: irrigation (water) }\end{array}$ & Topical ophthalmics, symptomatic care \\
\hline
\end{tabular}

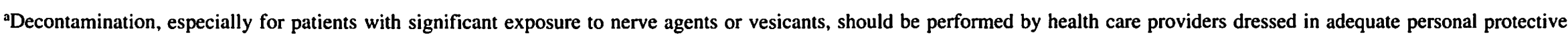
equipment. For emergency department staff, this consists of a non-encapsulated, chemically resistant body suit, boots, and gloves with a full-face air purifier mask/hood.

'Intraosseous route is likely equivalent to intravenous.

'Atropine might have some benefit via endotracheal tube or inhalation, as might aerosolized ipratropium.

'Pralidoxime is reconstituted to $50 \mathrm{mg} / \mathrm{ml}$ ( $1 \mathrm{~g}$ in $20 \mathrm{ml}$ water) for IV administration, and the total dose is infused over 30 min, or it may be given by continuous infusion (loading dose 25

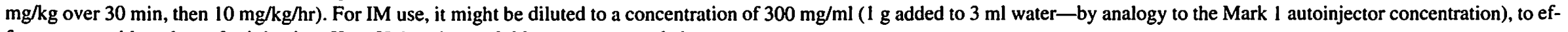
fect a reasonable volume for injection. Key: $\mathrm{Hgb}=$ hemoglobin; $\mathrm{prn}=$ as needed. 
agents. Panel recommendations were based on the presented data and the breakout group discussions. The consensus panel agreed that all plans for providing medications in the case of a terrorism event should include all agents listed in Tables 3 and 4, including appropriate pediatric forms and dosages. This would include stocking and deployment of these agents through the SNS and state and local health departments (push packs, vendormanaged inventory, etc.). The panel also agreed that there should be treatment provisions for local responders and that adequate stocks of antidotes (especially for nerve agents) should be available for use by EMS and hospital emergency departments. The panel also noted the need to have stocks of cyanide antidote, along with clear, size-adjusted dosing regimens. The panel further concluded that risk assessment should be used to determine the quantity of stock items, based on the estimated numbers of all possibly exposed children and estimates of children being transported for treatment.

One of the key evidence-based conclusions of the panel was support for use of the Mark-1 Autoinjector kits in cases of chemical terrorism with nerve agents. These kits are not currently approved for pediatric use. However, the panel concluded that they provide good initial treatment for children with severe, life-threatening nerve agent toxicity when IV treatment is not possible or available, or when more precise IM $(\mathrm{mg} / \mathrm{kg})$ dosing would be logistically impossible. The panel also concluded that U.S. approval of a pediatric autoinjector kit that is currently produced and marketed abroad should be expedited.

Further, the U.S. should strongly consider developing a universal, length-based dosing system (such as the Luten-Broselow color coding paradigm) for chemical agent antidotes and other critical medications for use in terrorism events.
The panel noted that educational material on pediatric treatment for chemical terrorism is limited. As such, the panel found a need for an organized body of knowledge regarding chemical weapons and children. This educational material should be readily available to pediatric and emergency services health-care professionals and should include information about the known pediatric toxicology of chemical weapons, management protocols based on a consensus guideline-development process, and real-time contact resources (e.g., poison control centers, CDC, etc.). In addition, the panel concluded that educational programs on chemical terrorism should be made available to EMS and community health-care workers (e.g., school nurses). These programs should be part of an ongoing training and assessment process.

Radiological terrorism. A key panel recommendation was to plan for and develop distribution systems for $\mathrm{KI}$ [potassium iodide] in all localities. The panel noted that $\mathrm{KI}$ is a valuable treatment for children exposed to radioiodines. Local areas should have the capability of being able to treat all children with $\mathrm{KI}$ within 2 hours of exposure to radioactive iodine. Community risk assessment should be used to determine the potential need for $\mathrm{KI}$, based on the estimated pediatric population that could be exposed to a minimum of $5 \mathrm{cGy}$ radioactive iodine. Typically, this at-risk population resides within at least a 10mile radius of a release, although a 50-mile radius is possible under some conditions.

The panel recommended graded $\mathrm{KI}$ dosing based on age (Table 5) whenever possible. If local emergency planners conclude that graded dosing is logistically impractical for populations at risk of radioiodine exposure, then $130 \mathrm{mg}$ of $\mathrm{KI}$ should be administered. The overall benefits of receiving $130 \mathrm{mg}$ of $\mathrm{KI}$ instead of the lower doses recommended for certain age groups far exceed the small risks

TABLE 4. Autoinjector USAGE

\begin{tabular}{lcccc}
\hline $\begin{array}{l}\text { Approximate } \\
\text { age }\end{array}$ & $\begin{array}{c}\text { Approximate } \\
\text { weight }\end{array}$ & $\begin{array}{c}\text { Number of } \\
\text { autoinjectors } \\
\text { (each type })\end{array}$ & $\begin{array}{c}\text { Atropine } \\
\text { dosage range } \\
(\mathrm{mg} / \mathrm{kg})\end{array}$ & $\begin{array}{c}\text { Pralidoxime } \\
\text { dosage range } \\
(\mathrm{mg} / \mathrm{kg})\end{array}$ \\
\hline $3-7 \mathrm{yrs}$ & $13-25 \mathrm{~kg}$ & 1 & $0.08-0.13$ & $24-46$ \\
$8-14$ yrs & $26-50 \mathrm{~kg}$ & 2 & $0.08-0.13$ & $24-46$ \\
$>14 \mathrm{yrs}$ & $>51 \mathrm{~kg}$ & 3 & 0.11 or less & 35 or less \\
\hline
\end{tabular}

Note: Each Mark-1 kit contains two autoinjectors (0.8-inch needle insertion depth), one each of atropine $2 \mathrm{mg}(0.7 \mathrm{ml})$ and pralidoxime $600 \mathrm{mg}$ ( $2 \mathrm{ml}$ ); while not approved for pediatric use, they should be used as initial treatment in circumstances for children with severe, life-threatening nerve agent toxicity for whom IV treatment is not possible or available or for whom more precise IM $(\mathrm{mg} / \mathrm{kg})$ dosing would be logistically impossible. Suggested dosing guidelines are offered; note potential excess of initial atropine and pralidoxime dosage for age/weight, although within general guidelines for recommended total over first 60-90 min of therapy for severe exposures. This table lists usage of the Mark-I kit only down to age 3 based on adherence to recommended dosages for atropine and pralidoxime. However, if an adult Mark-1 kit is the only available source of atropine and pralidoxime after a bona fide nerve agent exposure, it should be administered to even the youngest child. 
TABle 5. DOSE Guidelines for KI Administration

\begin{tabular}{lcc}
\hline Patient/Age & Exposure, Gy $(\mathrm{rad})$ & KI dose $^{\mathrm{a}}(\mathrm{mg})$ \\
\hline$>40$ years of age & $>5(500)$ & 130 \\
$18-40$ years of age & $0.1(10)$ & 130 \\
12 through 17 years of age & $0.05(5)$ & 65 \\
4 through 11 years of age & $0.05(5)$ & 65 \\
1 month through 3 years of age & $0.05(5)$ & 32 \\
Birth through 1 month of age & $0.05(5)$ & 16 \\
Pregnant or lactating women & $0.05(5)$ & 130 \\
\hline
\end{tabular}

This table was created from recommendations developed at the consensus conference and is based in part on reviewed reference materials from AAP, CDC, and FDA.

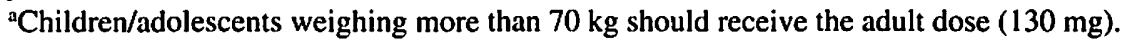

of overdosing. Similarly, KI dosing based on projected thyroid radioactive exposure may be logistically impractical during a radiological emergency. In this case, KI should be administered to children to protect them from at least a $0.05 \mathrm{~Gy}$ projected internal thyroid exposure.

The panel agreed that the government should facilitate development of a pediatric preparation of $\mathrm{KI}$, in an effort to make pediatric dosing more practical. In general, the $\mathrm{KI}$ dosing should follow the recommendations in Table 5 and Figures 5 and 6, except as noted above.

The panel noted a need for appropriate agents, in addition to $\mathrm{KI}$, for radiological events, including agents to stimulate bone marrow. These agents are important for children who may be victims of radiological terrorism or who may be exposed to radioactive materials through a nonterrorist event. Recommendations based on available marrow-stimulative agents and their dosages are listed in Table 6. The panel also agreed that medication stockpiles should include adequate stocks of anti-emetics to treat the emesis caused by this exposure and to prevent dehydration, to which children have increased susceptibility.

Finally, the panel agreed on the need to stock the medications for treatment of radiological exposure by agents other than radioactive iodine. These agents and the recommended treatments are listed in Table 7. Furthermore, children should always be considered in testing of these agents and agents to be developed in the future and their treatment protocols.

Physical protection. There is little role for physical protection (e.g., personal protection devices) against bioterrorist agents in a civilian population. Although some companies are marketing devices such as gas masks for children, the panel felt that the risks of using these are likely to outweigh the benefits. For example, reports exist of Israeli children suffocating after donning gas masks during Operation Desert Storm. However, research into future means of physical protection must consider the needs of children.

Figure 5. Guidelines for Home Preparation of Ki Solution Using 130-mg Tablet

1. Put one $130-\mathrm{mg} \mathrm{KI}$ tablet in a small bowl and grind into a fine powder with the back of a spoon. The powder should not have any large pieces.

2. Add $4 \mathrm{tsp}(20 \mathrm{~mL})$ of water to the KI powder. Use a spoon to mix them together until the $\mathrm{KI}$ powder is dissolved in the water.

3. Add 4 tsp ( $20 \mathrm{~mL}$ ) of milk, juice, soda, or syrup (e.g., raspberry) to the $\mathrm{KI} /$ water mixture. Potassium iodide mixed with any of the recommended drinks will keep for up to 7 days in the refrigerator.

4. The resulting mixture is $16.25 \mathrm{mg}$ of $\mathrm{KI}$ per teaspoon $(5 \mathrm{~mL})$.

5. Age-based dosing guidelines:

Newborn through 1 month of age $=1$ tsp

1 month through 3 years of age $=2$ tsp

4 years through 17 years of age $=4 \mathrm{tsp}$ (Children/adolescents weighing more than $70 \mathrm{~kg}$ should receive one $130-\mathrm{mg}$ tablet.)

This figure was created from recommendations developed at the consensus conference and is based in part on reviewed reference materials from AAP, CDC, and FDA. 
Figure 6. Guidelines for Home Preparation of Ki Solution Using 65-Mg Tablet"

1. Put one 65-mg KI tablet in a small bowl and grind into a fine powder with the back of a spoon. The powder should not have any large pieces.

2. Add $4 \mathrm{tsp}(20 \mathrm{~mL})$ of water to the KI powder. Use a spoon to mix them together until the $\mathrm{KI}$ powder is dissolved in the water.

3. Add 4 tsp ( $20 \mathrm{~mL}$ ) of milk, juice, soda, or syrup (e.g., raspberry) to the $\mathrm{KI} /$ water mixture. Potassium iodide mixed with any of the recommended drinks will keep for up to 7 days in the refrigerator.

4. The resulting mixture is $8.125 \mathrm{mg}$ of $\mathrm{Kl}$ per teaspoon $(5 \mathrm{~mL})$.

5. Age-based dosing guidelines:

Newborn through 1 month of age $=2$ tsp

1 month through 3 years of age $=4$ tsp

4 years through 17 years of age $=8$ tsp or one $65-\mathrm{mg}$ tablet (Children/adolescents weighing more than $70 \mathrm{~kg}$ should receive two $65-\mathrm{mg}$ tablets.)

This figure was created from recommendations developed at the consensus conference and is based in part on reviewed reference materials from AAP, CDC, and FDA.

Decontamination. The panel discussed the need to design decontamination systems so that they can be used for children of all ages (including infants). These systems should include pediatric considerations related to water temperature and pressure (i.e., high-volume, low-pressure, heated water systems), nonambulatory children, parentless children, and children with special health-care needs. There is also a need to provide clean clothes for children after they have been decontaminated. In general, the above considerations need to be addressed in all federal, state, regional, and local protocols and guidance documents.

Strategic National Stockpile. The panel concluded that the SNS must address the unique needs of children in many areas, including:

- assuring availability of pediatric supplies in all phases of a disaster;

- using age and weight considerations to allocate inventory percentages;
- providing pediatric dosing schedules and formulations; - providing current, individualized packing; and

- providing pediatric expertise for the overall SNS program, as well as during planning and implementation.

The distribution of pediatric-specific supplies, including the SNS, should be coordinated in state, regional, and local disaster plans. The SNS must require external review by a federal multidisciplinary pediatric advisory board for all federal, state, regional, and local equipment and pharmaceutical stockpiles.

\section{CONCLUSIONS}

The consensus-building process described above represented a major step forward in pediatric preparedness for disaster and terrorist events. This process resulted in a set of recommendations and guidelines to address the particular vulnerabilities of children to terrorist attacks or

Table 6. Marrow Stimulative Agents

\begin{tabular}{llc}
\hline Agent & \multicolumn{1}{c}{ Action } & \multicolumn{1}{c}{ Dosage $^{\mathrm{b}}$} \\
\hline Epoetin Alpha ${ }^{\mathrm{a}}$ (Epogen, Procrit) & Induces erythropoieses & $150 \mathrm{units} / \mathrm{kg} /$ dose \\
Filgrastim (Neupogen) & Granulocyte Colony & $2.5-5 \mathrm{mcg} / \mathrm{kg} / \mathrm{day}$ (dosages of $20 \mathrm{mcg} / \mathrm{kg} / \mathrm{day}$ \\
& Stimulating Factor (GCSF) & may be needed in selected patients) \\
Sargramostim (Leukine) & Colony & $5-10 \mathrm{mcg} / \mathrm{kg} /$ day (dosages of $30 \mathrm{mcg} / \mathrm{kg} / \mathrm{day}$ \\
& Stimulating Factor (AMCSF) & may be needed in selected patients) \\
\hline
\end{tabular}

aEpoetin Alpha may also be useful to reduce the overall requirements for blood transfusion in any mass casualty incident.

'Dosage derived from Medical Management of Radiological Casualties, Armed Forces Radiobiology Research Institute, 1999, and accepted dosages for pediatric oncology and pediatric congenital neutropenia and erythropenia patients. 
Table 7. Radionuclides Produced after Radiological Terrorism or Disaster-INTERnal CONTAMINATION, TOXICITY, AND TREATMENT ${ }^{1,2.13}$

\begin{tabular}{|c|c|c|c|c|c|}
\hline Element & $\begin{array}{l}\text { Respiratory } \\
\text { absorption }\end{array}$ & GI absorption & $\begin{array}{l}\text { Skin wound } \\
\text { absorption }\end{array}$ & Primary toxicity & Treatment \\
\hline Americium & $75 \%$ & Minimal & Rapid & $\begin{array}{l}\text { Skeletal deposition } \\
\text { Marrow suppression, } \\
\text { hepatic deposition }\end{array}$ & $\begin{array}{l}\text { Chelation with DTPA } \\
\text { or EDTA }\end{array}$ \\
\hline Cesium & Complete & Complete & Complete & $\begin{array}{l}\text { Whole body } \\
\text { irradiation }\end{array}$ & Prussian blue \\
\hline Cobalt & High & $<5 \%$ & Unknown & $\begin{array}{l}\text { Whole body } \\
\text { irradiation }\end{array}$ & Supportive \\
\hline Iodine & High & High & High & $\begin{array}{l}\text { Thyroid ablation, } \\
\text { carcinoma }\end{array}$ & Potassium iodide \\
\hline Phosphorus & High & High & High & $\begin{array}{l}\text { Bone, rapidly } \\
\text { replicating cells }\end{array}$ & Aluminum hydroxide \\
\hline Plutonium & High & Minimal & $\begin{array}{l}\text { Limited, may } \\
\text { form nodules }\end{array}$ & Lung, bone, liver & $\begin{array}{l}\text { Chelation with DTPA } \\
\text { or EDTA }\end{array}$ \\
\hline Radium & Unknown & $30 \%$ & Unknown & $\begin{array}{l}\text { Bone, marrow } \\
\text { suppression, sarcoma }\end{array}$ & $\begin{array}{l}\text { Magnesium sulfate } \\
\text { lavage }\end{array}$ \\
\hline Strontium & Limited & Moderate & Unknown & Bone & Supportive \\
\hline Tritium & Minimal & Minimal & Complete & Panmyelocytopenia & $\begin{array}{l}\text { Dilution with controlled } \\
\text { water intake, diuresis }\end{array}$ \\
\hline Tritiated water & Complete & Complete & Complete & Panmyelocytopenia & $\begin{array}{l}\text { Dilution with controlled } \\
\text { water intake, diuresis }\end{array}$ \\
\hline Uranium & High & $\begin{array}{l}\text { High to } \\
\text { moderate }\end{array}$ & $\begin{array}{l}\text { High absorption, } \\
\text { skin irritant }\end{array}$ & $\begin{array}{l}\text { Pulmonary, } \\
\text { nephrotoxic }\end{array}$ & $\begin{array}{l}\text { Chelation with DTPA } \\
\text { or EDTA, NaHCO }{ }_{3} \text { to } \\
\text { alkalinize urine }\end{array}$ \\
\hline
\end{tabular}

disasters, as well as possible responses to these scenarios. However, the development of these recommendations and guidelines is only the first step in improving disaster and terrorism preparedness for children. The next step is to ensure that these recommendations reach the individuals with the authority to make decisions regarding their adoption, as well as those who will be putting them into use.

In the future, we need to enhance our knowledge base regarding children's needs. This will require funding of the research agenda by Congress, the National Institutes of Health, and other federal agencies responsible for preparedness. We plan to reconvene this panel in one year to evaluate the current state of implementation of the recommendations and guidelines, to update the recommendations as needed based on new research, and to plan the continuing research agenda.

\section{ACKNOWLEDGMENTS}

This effort was funded by grant number $1 \mathrm{R} 13$ HS13855 from the Agency for Healthcare Research and Quality and by grant number $1 \mathrm{H} 34 \mathrm{MC} 00122-01$ from the EMSC Program of the Maternal and Child Health Bureau, Health Resources Services Administration, Department of Health and Human Services, and by the Children's Health Fund. The authors would like to thank these organizations for providing the financial support for this project. We thank Sally Phillips and Carole Dillard and their staff, whose help was invaluable to the success of this project; and David Heppel, MD, and Dan Kavanagh, MSW, of the MCHB, HRSA, for their direction and assistance with this project and with the meeting. We thank our copy editor Susan E. Aiello, DVM, for her exemplary and tireless efforts, which were essential to the creation of this document. The authors thank the staff of the National Center for Disaster Preparedness and the Children's Health Fund, whose help in the logistics and onsite support of the meeting and group discussions were invaluable. Lastly, we thank all the organizations and agencies and their representatives who participated, shared their expertise, and fostered the process, and without whom this work would have never been accomplished. 


\section{REFERENCES}

1. Redlener I, Markenson D. Disaster and terrorism preparedness: what pediatricians need to know. Adv Pediatr 2003; 50:1-37.

2. Pynoos RS, Nader K. Mental health disturbances in children exposed to disaster: preventive intervention strategies. In: Goldston SE, Yaker J, Heinicke CM, Pynoos RS, eds. Preventing Mental Health Disturbances in Childhood. Washington, DC: American Psychiatric Press; 1990:211-234.

3. Sugar M. Children in a disaster: an overview. Child Psychiatry Hum Dev 1989;19:163-179.

4. Sugar M. Disasters. In: Levine MD, Carey WB, Crocker AC, eds. Developmental-Behavioral Pediatrics. 2nd ed. Philadelphia, Pa: WB Saunders Co; 1992:178-181.

5. Vogel JM, Vernberg EM. Children's psychological responses to disasters. J Clin Child Psychol 1993;22:464-484.

6. Saylor CF, Swenson C, Powell P. Hurricane Hugo blows down the broccoli: preschoolers' post-disaster play and adjustment. Child Psychiatry Hum Dev 1992;22:139-149.

7. Sugar M. A preschooler in a disaster. Am J Psychother 1988;42:619-629.

8. Shannon MP, Lonigan CJ, Finch AJ Jr, Taylor CM. Children exposed to disaster. I. Epidemiology of post-traumatic symptoms and symptom profiles. J Am Acad Child Adolesc Psychiatry 1994;33:80-93.

9. La Greca AM, Vernberg EM, Silverman WK, Vogel AL, Prinstein MJ. Helping Children Prepare for and Cope with Disasters: A Manual for Professionals Working with Elementary School Children. Coral Gables, Fla: University of Miami; 1993.

10. Holbrook PR. Pediatric disaster medicine. Crit Care Clin 1991;7(2):463-470.

11. Carley SD, Mackway-Jones K, Donnan S. Delphi study into planning for care of children in major incidents. Arch Dis Child 1999;80(5):406-409.

12. Mackway-Jones K, Carley SD, Robson J. Planning for major incidents involving children by implementing a Delphi study. Arch Dis Child 1999;80(5):410-413.

13. van Amerongen RH, Fine JS, Tunik MG, Young GM, Foltin GL. The Avianca plane crash: an emergency medical system's response to pediatric survivors of the disaster. Pediatrics 1993;92(1):105-110.

14. Quinn B, Baker R, Pratt J. Hurricane Andrew and a pediatric emergency department. Ann Emerg Med 1994;23:737-741.

15. Takada S, Shintani Y, Sohma O, Tsuneishi S, Uetani Y, Nakamura H. Difficulties of families with handicapped children after the Hanshin-Awaji earthquake. Acta Paediatr Jpn 1995;37(6):735-740.

16. Shimada $S$, Funato $M$. Home mechanical ventilation in the aftermath of the Hanshin-Awaji earthquake disaster. Acta Paediatr Jpn 1995;37(6):741-744.
17. Lamberg L. Children and families need help after disasters. JAMA 1996;275(22):1714-1715.

18. Damian F, Atkinson CC, Bouchard A, Harrington S, Powers T. Disaster relief efforts after Hurricane Marilyn: a pediatric team's experience in St. Thomas. $J$ Emerg Nurs 1997;23(6):545-549.

19. Committee on Pediatric Emergency Medicine. American Academy of Pediatrics. The pediatrician's role in disaster preparedness. Pediatrics 1997;99(1):130-133.

20. Committee on Psychosocial Aspects of Child and Family Health. American Academy of Pediatrics. How pediatricians can respond to the psychosocial implications of disasters. Pediatrics 1999; 103(2):521-523.

21. Committee on Environmental Health and Committee on Infectious Diseases. American Academy of Pediatrics. Chemical-biological terrorism and its impact on children: a subject review. Pediatrics 2000;105: 662-670.

22. Sharp TW, Brennan RJ, Keim M, Williams RJ, Eitzen E, Lillibridge $\mathrm{S}$. Medical preparedness for a terrorist incident involving chemical or biological agents during the 1996 Atlanta Olympic games. Ann Emerg Med 1998;32:214 223.

23. Christopher GW, Cieslak TJ, Pavlin JA, Eitzen EM Jr. Biological warfare. A historical perspective. JAMA 1997; 278(5):412-417.

24. Henderson DA. The looming threat of bioterrorism. Science 1999;283(5406):1279-1282.

25. Noji EK. Progress in disaster management. Lancet 1994; 343:1239-1240.

26. Jones J, Hunter D. Qualitative research: Consensus methods for medical and health services research. Brit Med $J$ 1995;311:376-380.

27. Dalkey N, Helmer O. An experimental application of the Delphi method to the use of experts. Manage Sci 1963;9: 458-467.

28. Linstone HA, Turoff M, eds. The Delphi Method: Techniques and Applications. Reading, Mass: Addison-Wesley; 1975.

29. Rowe G, Wright G, Bolger F. Delphi: a reevaluation of research and theory. Technol Forecast Soc Change 1991;39: 235-251.

30. Caves R. Consultative methods for extracting expert knowledge about professional competence. In: Ellis R, ed. Professional Competence and Quality Assurance in the Caring Professions. New York: Chapman \& Hall; 1988: 199-229.

31. Carcillo JA, Fields AI, American College of Critical Care Medicine Task Force Committee Members. Clinical practice parameters for hemodynamic support of pediatric and neonatal patients in septic shock. Crit Care Med 2002; 30(6):1365-1378. 


\section{Appendix A. Participants}

\section{Conference Chairs}

David Markenson, MD, FAAP, EMT-P

Director

Program for Pediatric Preparedness

National Center for Disaster Preparedness

Mailman School of Public Health

Columbia University

\section{Irwin Redlener, MD, FAAP}

Director

National Center for Disaster Preparedness

Mailman School of Public Health

Columbia University

President and Co-Founder

Children's Health Fund

Member, American Academy of Pediatrics' Taskforce on Terrorism

\section{Conference Coordinators}

\section{George Foltin, MD, FAAP, FACEP}

Director, Center for Pediatric Emergency Medicine

Bellevue Hospital Center/NYU School of Medicine

New York University School of Medicine

Arthur Cooper, MD, FACS, FAAP, FCCM

Director of Trauma and Pediatric Surgical Services

Columbia University Affiliation

Harlem Hospital Center

\section{Expert Consultants}

Richard Aghababian, MD, FACEP

University of Massachusetts Memorial Health Care

Lisa Bernardo, RN, PhD, MPH

Associate Professor, University of Pittsburgh

Richard Bissell, PhD

Department of Emergency Health Services

University of Maryland Baltimore County

Theodore Cieslak, MD

Chief, Department of Pediatrics

Pediatric Infectious Disease Tropical Medicine

Flight Surgery, San Antonio Military Pediatric Center

Brooks Army Medical Center, U.S. Army

Christina Hoven, PhD

Columbia University
Jeffrey Meade, NREMT-P, NYCIC

Manager, Emergency Life Support Programs

Phelps Memorial Hospital Center

Deborah Mulligan-Smith, MD, FAAP, FACEP

Director and Professor, Institute for Child Health Policy

Lou Romig, MD, FAAP, FACEP

Pediatric Emergency Medicine Attending Physician/

EMS Liaison, Medical Director

Robert Wadell, EMT-P

\section{Government Agency Representatives}

Victor Balaban, PhD

National Center for Injury Prevention and Control

Centers for Disease Control and Prevention

Dhana Batts-Osborne, MD, FACEP

Medical Officer

Centers for Disease Control and Prevention/National Center for Environmental Health

Cheryl A. Boyce, PhD

National Institute of Mental Health/Developmental

Psychopathology and Prevention Branch

Carole Dillard, MA

Agency for Healthcare Research and Quality

Marjorie Geiger, MPH

Assistant Director, Bureau of EMS

New York State Department of Health

David Heppel, MD

Maternal and Child Health Bureau

Health Resources Services Administration

Department of Health and Human Services

\section{Lynne Haverkos, MD, MPH}

Director, Behavioral Pediatrics and Health Promotion

National Institute of Child Health and Human

Development

Tom Lawrence, NREMPT-P

Rhode Island DMAT/EMSC 
Brad Leissa, MD

Lead Medical Officer, Division of Counter Terrorism

Centers for Drug Evaluation and Research

Food and Drug Administration

Amy Loy, BA

Office of Terrorism Preparedness and Emergency Response

Centers for Disease Control and Prevention, Office of the Director

Suma Nair, MS, RD

Public Health Analyst/HRSA Scholar

Health Resources Services Administration

Carol Nicholson, MS, MD, FAAP

Program Director, Pediatric Critical Care and

Rehabilitation Research

National Institute of Child Health and Development

National Center for Medical Rehabilitation Research

Nicki Pesik, MD

Senior Medical Consultant, Strategic National Stockpile

Centers for Disease Control and Prevention

Sally Philips, PhD, RN

Director of Bioterrorism Preparedness Research

Program

Agency for Healthcare Research and Quality

Neil Richmond, MD

Deputy Medical Director

New York City Fire Department

William Rodriguez, MD, PhD

Science Director for Pediatrics

Center for Drug Evaluation and Research Office of

Counter Terrorism and Preparedness

Food and Drug Administration

Trista Sims, MPH, CHES

EMSC Program, Maternal and Child Health Bureau

Health Resources Services Administration

Rick Smith

Chief Injury and EMS Branch

Health Resources Services Administration

\section{Gregory Thomas}

Executive Director, Office of School Safety and Planning

New York City Department of Education

\section{Professional Organization Representatives}

Samuel Alaish, MD, American Pediatric Surgical Association

Ken Allen, EMSC National Resource Center

Anne Balboni, PhD, International Critical Incident Stress Foundation

Nancy Blake, RN, MN, National Association of Children's Hospitals and Related Institutions

Nancy Bourgeois, RN, BSN, National Association of State EMS Directors

Kathleen Brown, MD, National Association of EMS Physicians

Joe Cappiello, Joint Commission on Accreditation of Healthcare Organizations

Mirean Coleman, BA, MSW, LICSW, National Association of Social Workers

Bonnie Connors-Jellen, MHSA, American Hospital Association

Michael Ely, MHRM, National EMSC Data Analysis Resource Center

Lynne Fairobent, American College of Radiology

Nicole Finn, Joint Commission on Accreditation of Healthcare Organizations

Michael Glasstetter, JD, American Academy of Pediatrics

Roy Grant, MA, Children's Health Fund

Kathy Haley, RN, BSN, Emergency Nurses Association

Fred Henretig, MD, American Academy of Pediatrics

Ellen K. Heyneman, MD, American Academy of Child and Adolescent Psychiatry

Peter Holbrook, MD, National Association of Children's Hospitals and Related Institutions

Patricia Jocius, BA, MA, CEM, International Association of Emergency Managers

Annette LaGreca, PhD, American Psychological Association

Ann Langley, National Association of Children's Hospitals and Related Institutions

Shulamit Lewin, MHS, International Center to Heal Our Children

Tommy Loyacono, EMT, National Association of EMTs

Edwin Lyman, PhD, Nuclear Control Institute

Michelle McKee, MD, National Association of Children's Hospitals and Related Institutions

Isabelle Melese-d'Hospital, PhD, EMSC National Resource Center

Jennifer Mincin, National Organization on Disability Garrett Nanninga, American Red Cross

Dana Nicholson, MBA, MS, RN, Society of Pediatric Nurses 
Susan Paula, PhD, Children's Health Fund Denice Reese, RN, MSN, CPNP, National Association of School Nurses

David Schonfeld, MD, FAAP, American Academy of Pediatrics
Mark Thorp, International Association of Fire Chiefs

Doris Varlese, JD, Greater NY Hospital Association

Bob Wise, MD, Joint Commission on Accreditation of Health Organizations

Note: These individuals were appointed to represent their organizations, and the comments contained in this document represent input from these participants. However, formal approval of this summary was not obtained from the boards of these organizations. 